\title{
The effectiveness of Teaching with Analogy on Students' Mathematical Representation of Derivative Concept
}

\author{
Gelar Dwirahayu, Siti Miftah Mubasyiroh, Afidah Mas'ud \\ Syarif Hidayatullah State Islamic University Jakarta, J1. Ir. H. Djuanda 95, Ciputat, Indonesia \\ Corresponding e-mail: gelar.dwirahayu@uinjkt.ac.id
}

\begin{abstract}
The purpose of this study was to describe the effectiveness of Teaching with Analogy (TWA) model to increase students' mathematical representation. Teaching with Analogy is a learning model that provides guidelines to build linkages between something is already known and something new to learn or learn abstract concept through other concept that have learned before or daily life context. The analogy in this research consists of two ideas, analogy to the daily life and analogy to others concept. The concept of derivative function is a subject matter was using in this research, because most of students did not understand the meaning of formula $f^{\prime}(x)=\lim _{h \rightarrow 0} \frac{f(x+h)-f(x)}{h}$. We began the lesson with the analogy to daily life situation "speed of vehicle" to find the definition of first derivative. Then to explain second derivative we use analogy to concept first derivative. Mathematical representation is define as students' ability to express their ideas on mathematics as visual representation, images/graph, or create a mathematical model. This research was conducted at one of senior high school at Depok city for academic year 2016/2017. The method is quasiexperiment with Randomized Post-test Only Control Group Design. There are two classes are used, one class as the experimental which is students learns mathematics by TWA and the others as control class which is students learn mathematics without analogy. Data was collected using test of mathematical representation. The results show that students' mathematical representation who teach by model TWA is higher than students mathematical representation who teach without analogy.
\end{abstract}

Keywords: teaching with analogy, derivative function, mathematical representation

\section{INTRODUCTION}

Mathematics is one of school subjects, and derivative is one of the mathematical concepts. . The mathematics is abstract (Mitchelmore, 2004). Derivative function usually is defined as the opposite of integral, students does not understand what is the meaning of derivative function related to daily life.

Teacher gives explanation some formula of derivative function. In the end, teacher gives students some task.

For example: draw the graph for the function: $f(x)=\frac{1}{3} x^{3}-\frac{5}{2} x^{2}-6 x+7$.

To draw the graph, students do the following conventional technique:

a. Change $f(x)$ into the first derivative function to find maximum and minimum point, ' $f$ ' $(x)=x^{2}-5 x-6$ b. Making a table which consists of a random numbers and substitute the number for the function.

\begin{tabular}{|c|c|c|c|c|c|c|}
\hline$x$ & -2 & -1 & 0 & 1 & 2 & 3 \\
\hline$f(x)$ & 6.3 & 10.2 & 7 & -1.2 & -12.3 & -24.5 \\
\hline
\end{tabular}

c. Students draw a graph based on the table

Figure 1. Students work on derivative case.

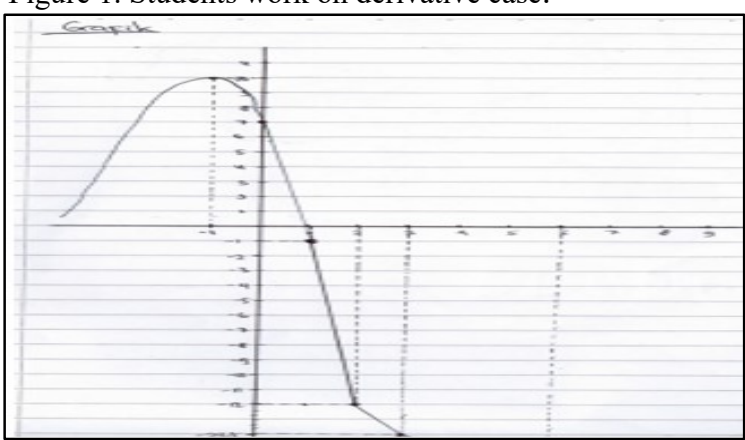


Figure 1 show the students work on make a graph for function: $f(x)=\frac{1}{3} x^{3}-\frac{5}{2} x^{2}-6 x+7$.

But, students did not understand what this question mean. What the students solve that problem for?

Mathematics is a representation (Brown, 2010) of many concepts. Some examples of mathematical representation: are blood flows through a blood vessel, speed of the vehicle, population growth, volcano motion, etc. Representation should be teach in mathematics because mathematical representation is used to understand of mathematical concept (NCTM, 2000). Most of teachers teach mathematics demand on cognitive mastery, students are given some task with the emphasis on using of formulas without exercising their representation skills. It can help students understand math through physical objects, drawings, charts, graphs, and symbols. It also helps them s communicate their thinking (Hatfield, 2008). Through representation, students can develop and optimize their' thinking skills by a construct of mathematical knowledge (Rahmawati, 2017). In this research, mathematical representation is categorized into three aspects as a visual: present a problem in the form of graph, picture, or diagram, symbolic: present problems in the form of algebraic operations and solve it, and verbal: express problems with your own language.

Mathematical representations of the students who were taught in control group with a conventional approaches will not develop well, as the conventional approach is more informative or transfer of knowledge, while teaching with analogies causes a significantly better acquisition of scientific concepts and help students integrate knowledge more effectively (Samara, 2016). In this research, analogy is defined in two terms; the first analogy is commonly devised in everyday experience, spoken and written communication when trying to make familiar the unfamiliar, to compare one object or situation to another (Duit, 1991), and build conceptual bridges between what is familiar and what is new (Glyn, 2007), and the second, analogy is defined as a comparison of the similarities of two concepts (Aberšek, 2016). We can use students' past knowledge, experiences and preferences (Allan, 2006) as a trigger to understand new concepts from daily experience or similarities in the last concepts.

\section{METHODS}

An experimental research with randomized post-test only control group design was conducted to train teaching with analogy at Senior High School at
Depok City s from April to May 2017. The sample was 94 eleventh grade students. The experiment class consisted of 43 students and control class consisted of 42 student, and instrument of representation test comprised 5 essays used to collect data.

The instrument has been validated by nine colleagues and a teacher of mathematics. Using formula of $C V R=\frac{\left(n_{e}-\left(\frac{N}{2}\right)\right)}{\left(\frac{N}{2}\right)}$ (Lawshe, 1975), the results showed that three items were valid and two items were invalids. For the invalids' items, the questions were revised on the basis of validators' recommendations. The calculation of reliability using Cronbach's Alpha resulted in $r=0.730$ (high category).

\section{RESULTS AND DISCUSSION}

The research is implementation for seven times. It conducted in class experiment teaching with analogy and at class control teaching with a conventional approach. The findings of this study $x_{e}=61, s d_{e}=$ $12.64 x_{c}=52, s d_{c}=11.69$, and using $t$-test we get sig $=0.003<\mathrm{p}$ value we can conclude that students' mathematic representation who were taught by teaching with analogy is higher than students' mathematics representation who were taught by a conventional method.

At the beginning of learning process, students understand derivative function through daily life problem (Duit, 1991) such as: speed rate of a vehicle, which is defined as:

$$
f^{\prime}(x)=v_{i}=\frac{\Delta s}{\Delta t}=\frac{f\left(t_{2}\right)-f\left(t_{1}\right)}{\left(t_{2}\right)-\left(t_{1}\right)}
$$

This formula is related to physic formula and the students find such definition of derivative function as:

$$
f^{\prime}(x)=\lim _{h \rightarrow 0} \frac{f(x+h)-f(x)}{h}
$$

Another concept is similarity concept (Aberšek, 2016). For example, students are given analog concept of maximum and minimum with a graph of a function to understand stationary point as a derivative of a function. 
Figure 2. Graph of function $f=x(x-6)^{2}$

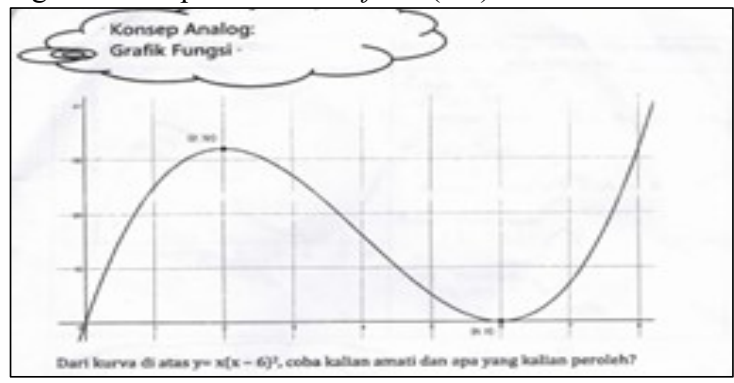

The activity of the stage is identifying the relevant features between concept target and concept analog, mapping the relevant nature equations between analog and target, showing the damage of analogies or identifying irrelevant properties between target and analog.

Based on Figure 1, students are asked to compare the function graph and the rising function, the descending function, the minimum, maximum value. Furthermore, student discussion was held in a small group to find the solution. By filling in the table, the student can make the exact words from the information that has been obtained. Figure 3 shows the results of student work on the activity.

Figure 3. Students' work on stationer point

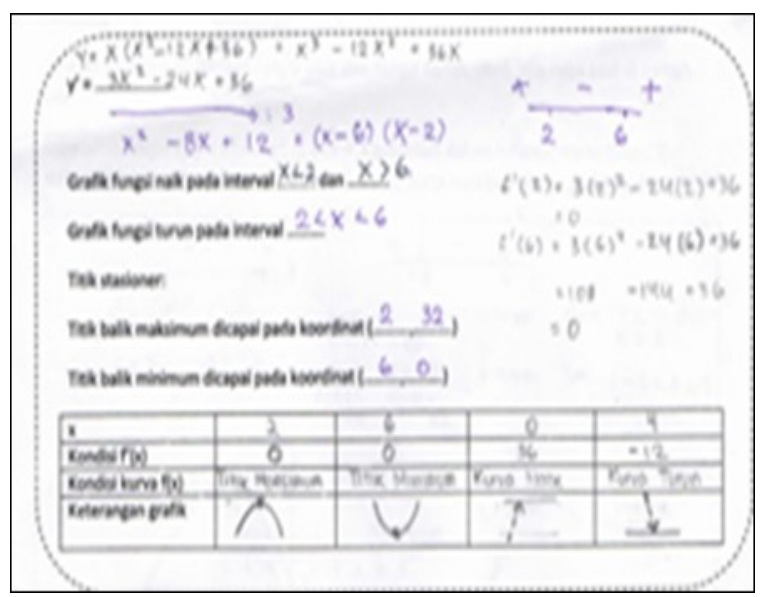

To understand the stationary point, students were asked to find the similarities of maximum and minimum points at a function graph; then they drew a conclusion regarding similarities between the maximum or minimum values on the graph a function with stationer value on derivative.
Figure 4. Students work on conclusion about up, down and turning points in a function

\begin{tabular}{|c|c|}
\hline \multicolumn{2}{|c|}{$\begin{array}{l}\text { Apa yang dapat kamu simpulkan tentang konsep fungsi naik, fungsi turun, titik } \\
\text { stasioner (maksimum, minimum, belok)? }\end{array}$} \\
\hline 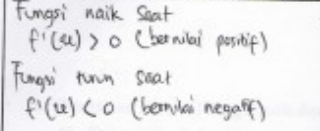 & $\begin{array}{l}\text { Mraksimum } \\
f^{\prime}(u)>0 \text { unnk } u<a \text { dan } \\
f^{\prime}(u)<0 \text { untk } u>a \text { atau } \\
f^{\prime}(u)=0\end{array}$ \\
\hline 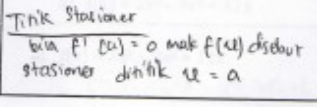 & $\begin{array}{l}\text { minimum } \\
f^{\prime}(u)<0 \text { untuk } u>a \text { dan } \\
\left.f^{\prime}(u)>0 \text { innk } u\right) \dot{a} \text { atav } \\
f^{\prime}(u)=0\end{array}$ \\
\hline - & $\begin{array}{l}\text { Belok } \\
f^{\prime}(u)<0 \text { untuk } u<a \text { dan } \\
f^{\prime}(u)<0 \text { unnk } u>a \text { aimu } \\
f^{\prime}(u)>0 \text { onhuk } u<a \text { dan } \\
f^{\prime}(u)<0 \text { untuk } u>a \text { atau } \\
f^{\prime}(u)=0\end{array}$ \\
\hline
\end{tabular}

Based on the diagram, students were asked to determine where is the up function, down function, constant function, maximum point, minimum point, and turning point. Using analogy with previous concept "equation in quadratic function", students made a difference between up function, down function, constant function, and they could find a position of maximum point at between up and down function, position minimum point at between down and up function, and turning point at between two of up function or down function (see Figure 4).

However, viewed from the indicators, teaching with analogy can enhance symbolic and visual representation only, as seen at Figure 5

Figure 5. Mathematical Representation Score based on Indicator

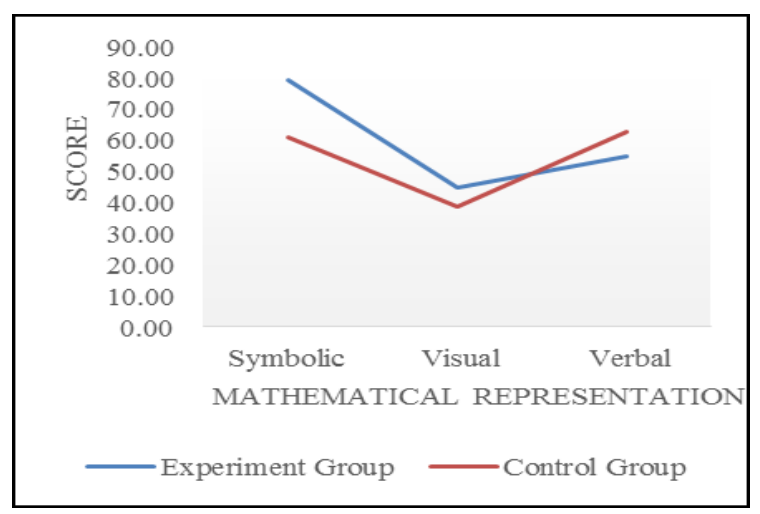

Based on the Figure 5, Symbolic representation for experiment class (79.36) is higher than control class $(61,01)$, Visual representation for experiment class (44.77) is higher than control class $(38,69)$, Visual representation for experiment class (44.77) is higher than control class $(38,69)$. Students' symbolic representation was trained during teaching and learning processes, where the students dealt with 
mathematical problems which were connected to daily life or previously concepts. The aim was that the students can make a notation or symbol that represents a problem and then solve it. Students' visual representation was trained by giving a picture related to the concept of derivative than students were ask to define or describe the picture based on it. Furthermore, visual representations were trained for the students who were confronted with the picture; then students were asked to analyze it and make some analogy according to the picture. While verbal skills have been trained where students faced with the state of the problem in the form of drawings or diagrams, then students were asked to express mathematical ideas by considering the image. But students preferred to use mathematical symbols or other images to solve the problem rather than verbal ones.

Here are the example questions for symbolic representation, visual representation, and verbal representation.

A rectangular field at the side of the highway, all will be fenced, except the exactly side of the highway. There are two kind of price of fenced. One side is $R p$. 120,000 per meter, other Rp. 80,000 per meter. Determine the size of the largest field that can be fenced with cost Rp. 36,000,000! (Symbolic representation)

$A$ line $12 x+6 y=72$ lies in a Cartesian coordinate. Point $B$ at the line, show the coordinate $B$, therefore, formed a rectangle with the maximum area? Show a picture and give your reasons! (Visual representation)

Subur Makmur Shop sells a variety of pastries, such as nastar, kastangel, kue salju and others. The price for one jar of nastar is Rp 50.000. Cakes in Subur Makmur are home-made. The production of cakes by Bu Aini incurred costs for $x$ jar of show in the equation $y=5 x^{2}-10 x+30$ (thousands rupiahs). Meanwhile, production cakes from Mrs. Lita incurred cost for $x$ jar of nastar show in the equation $y=2 x^{2}-15 x+50$. How many pieces of nastar cakes are entrusted by Mrs. Aini and Mrs. Lita? In your opinion, whose production gives more benefits to Subur Makmur? Explain!

\section{CONCLUSIONS}

Teaching with analogy can enhance the students' representation of a derivative function. Viewed form the indicator, teaching with analogy can improve students' symbolic and visual, representation 1, while teaching without analogy can improve students' verbal representation.

\section{ACKNOWLEDGEMENTS}

We would like to thank teachers and students at a senior high school in Depok City, Indonesia who have given their support during the period of research. . And our gratitude is delivered to colleagues in mathematics education department who have shared their ideas.

\section{REFERENCES}

Aberšek, B. (2016). Teaching with Analogies: Example of Self-Healing Porous Material. Journal: Problem of Education in The 21st Century, 70, 4-7

Harrison, A. G., Treagust, D. F. (2006). Teaching and Learning with Analogies. P. J. Aubusson et al. (eds.), Metaphor and Analogy in Science Education, 11, 1124. (C) Springer. Printed in the Netherlands.

Brown, S., Salter, S. (2010). Analogies in Science and Science Teaching. Journal: Advances in Physiology Education Published, 34(4), 167-169.

Lawshe, C. H. (1975). A quantitative Approach to Content Validity. Personel Psychology, INC, 567-568.

Duit, R. (1991). On the Role of Analogies and Metaphors in Learning Science. Journal: Science Education. 75(6), 649-672

Hatfield, et al. (2008). Mahematics Method for Elementary and Middle School Teachers Sixth Edition. Hoboken: John Wiley and Sons Inc.

Mitchelmore, M., White, P. (2004). Abtraction in Mathematics and Mathematics Learning, Proceedings of the 28th Conference of the International Group for the Psychology of Mathematics Education, 3, 329336.

National Council of Teachers of Mathematics. (2000). Principles and standards for school mathematics. Reston, VA: Author.

Rahmawati, D. (2017). Process of Mathematical Representation Translation from Verbal into Graphic. IEJME-Mathematics Education, 12(4), 367-381.

Samara, N. (2016). Effectiveness of Analogy Instructional Strategy on Undergraduate Student's Acquisition of Organic Chemistry Concepts in Mutah University, Jordan. Journal of Education and Practice, 7(8), 7074. 